\title{
The emergence of community strategic planning in New South Wales, Australia: Influences, challenges and opportunities
}

\author{
Jason Prior ${ }^{1}$ \\ Research Principal \\ Institute for Sustainable Futures, \\ University of Technology, Sydney

\section{Jade Herriman} \\ Research Principal \\ Institute for Sustainable Futures, \\ University of Technology, Sydney
}
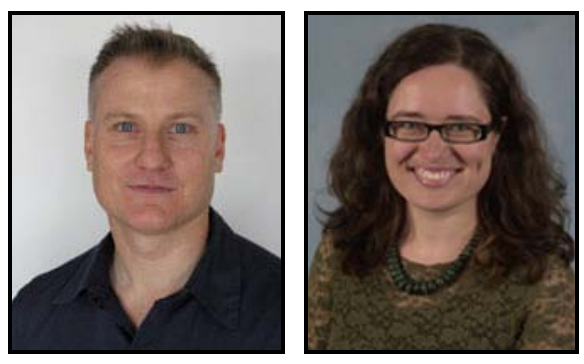

\begin{abstract}
This paper investigates the emergence of community strategic planning in the New South Wales (NSW) local government sector, against the backdrop of a series of broad influences ranging from increased interest in participatory democracy through to sustainable infrastructure provision. It provides an understanding of how community strategic planning has evolved over the past few decades to embody these influences. The paper concludes with reflections on some common challenges and opportunities experienced by local councils in NSW that have undertaken voluntary community strategic planning or are in the process of developing community strategic plans. Given underlying similarities in the emergence of participatory long-term strategic planningin local government around the world, many of the experiences associated with the preparation of community strategic plans in the NSW context are likely to be of relevance to those undertaking similar processes in other jurisdictions.
\end{abstract}

\section{Keywords}

Community, Strategic Planning, Participation and Engagement, New South Wales local government, Australian local government

\footnotetext{
1 The authors thank ISF Research Director Emma Partridge for early conceptual inputs into the community engagement aspects of this paper, and access to her recent research into community wellbeing indicators. They also acknowledge the councils named for their ongoing work in the domain of corporate, strategic and community planning and being the focus of this paper. However the views expressed and any made in interpreting their documents and experiences are solely ours.
} 


\section{Introduction}

Recent amendments to the NSW Local Government Act 1993 (NSWLG Act) require every local government in NSW to develop a minimum ten-year community strategic plan that is informed through "engagement with the local community", that is based on "social justice principles", and that acts as their principal planning document (see NSWLG Act 1993, s. 402(1)-(7)). This new planning framework offers a mechanism to embrace a series of influences that have affected local government over the past few decades. At the same time it presents ongoing challenges to local councils in formulating and implementing community strategic plans.

This paper begins with an overview of how community strategic planning and the plans it produces fit into the body of planning instruments within the NSW local government sector, and how community strategic planning has evolved over the past few decades. It then examines shifts in local governance and planning that have influenced the emergence of mandatory long-term, community-driven strategic planning. Finally, the paper examines some emerging challenges and opportunities, based on the observations of a number of councils that have recently completed or embarked upon the development of community strategic plans.

The influences, challenges and opportunities presented in the paper are based on a review of key literature, the documented experiences of councils who have undertaken community strategic planning (before or after the adoption of the new legislative requirements), researcher field notes on participation in various aspects of community strategic plan making, and the reflections and questions put forward by councils in industry forums held to discuss the new framework. The views expressed in this paper do not necessarily reflect those of the councils we refer to. While this paper focuses on NSW, we suggest that many of the issues discussed here are likely to have wider relevance, given underlying similarities in the emerging planning frameworks across Australia and in other countries in which state or national legislation now requires local government to engage the community in long-term strategic planning for local areas. Examples include New Zealand, which requires a councils to have a Long Term Council Community Plan $^{2}$ and the United Kingdom, which requires a Local Community

2 New Zealand Local Government Act 2002, part. 4 and 6. New Zealand, like the United Kingdom, has had a longer history of community-led strategic planning at a local level than New South Wales (Brady 2010). 
Strategy. ${ }^{3}$ This marks a shift over the last few decades towards strategic planning processes that seek to build long-term strategies on genuine engagement with the community and which allow communities to be fully involved in establishing both the long-term vision and priorities for action. ${ }^{4}$

\section{Community strategic plans and the evolution of local government planning}

This section of the paper gives a brief overview of the place of the community strategic plan within the evolving framework of planning instruments used by NSW local government (see Figure 1). The 152 councils in NSW have powers delegated to them through state government legislation. The Division of Local Government (NSWDLG) ${ }^{5}$ is the agency responsible for local governments across NSW. It is responsible for providing a clear policy and legislative foundation for local government, part of which includes the recent changes requiring each council to develop a 10-year community strategic plan.

Until recently the phrase strategic planning as used by NSW local government has tended to be synonymous with strategic land-use planning, regulated through the Environmental Planning and Assessment Act 1997 (NSWEP\&A) (see Figure 1) and concerned primarily with the built environment and land use activities. Within this context, local governments are required to prepare strategic land-use planning instruments for their local area, such as Local Environment Plans (zoning plans) and detailed Development Control Plans, together with associated compliance mechanisms to assess applications for development activities in light of those plans. However, the latter decades of the $20^{\text {th }}$ century saw the emergence of another form of strategic planning within NSW local government. It has been driven by a diverse series of influences such as the rise of participatory democracy, a desire for longer-term and more integrated forms of planning, and increasing concern about sustainability and social equity. It was also strongly influenced by the emergence of corporate planning within NSW local government.

\footnotetext{
${ }^{3}$ United Kingdom Local Government Act 2000, ch. 22, part. 1

${ }^{4}$ For example, New Zealand Local Government Act 2002, part 6.

${ }^{5}$ Until July 2010, the Division of Local Government was called the Department of Local Government.
} 
NSW Local Government Planning and Reporting Requirements

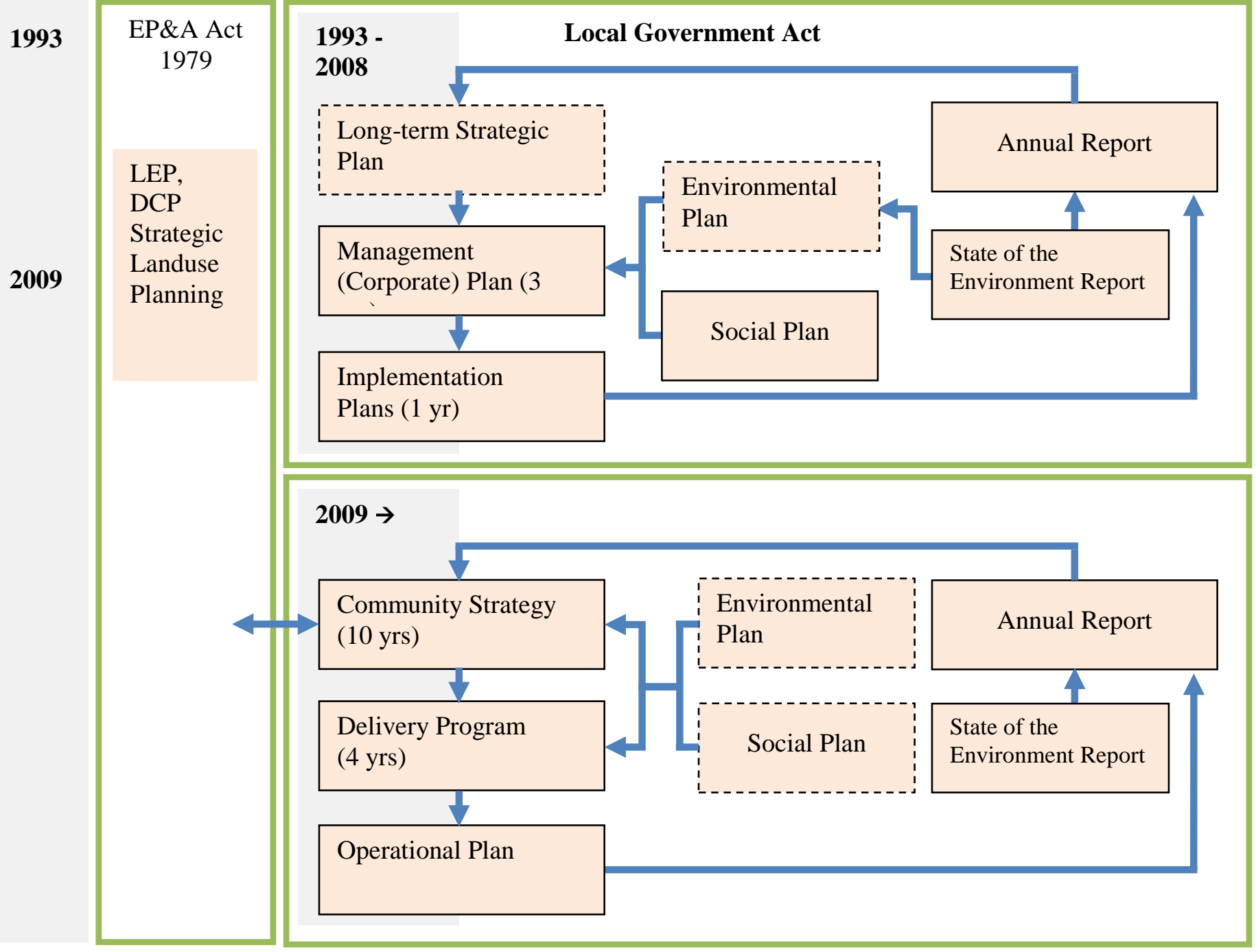

Figure 1: Community strategic planning as part of the evolving NSW local government planning framework (created by the authors) Note: Dashed lines indicate which plans are voluntary

The key instruments for corporate planning as set out in the NSWLG Act have until recently been the management plan and annual report, which are designed to be linked in coherent planning and reporting cycles (see Figure 1). The timeframe for management plans was at least three-years, with an annual update. Some councils interpreted the intent of the NSWLG Act as requiring both strategic and operational plans, which together address the legislative requirements for management planning. Other councils have developed longer-term strategic plans, even though this was not an explicit requirement of the legislation (see Figure 1). 
The voluntary nature of these early long-term strategic plans meant that local councils across NSW chose to design and implement them in a variety of ways. For example, whilst Penrith City Council's (PCC 2005) strategic plan was formulated primarily by councillors ${ }^{6}$ as representatives of the community, the neighbouring Blue Mountains City Council (BMCC) carried out an extensive community participation process (BMCC 2000b). BMCC first adopted a 25-year strategic plan in the 1970s (Berry \& Dillon 2005). The practical experience of developing long-term strategic plans within these innovative councils has arguably shaped the legislative context, providing legislators with tangible evidence of the feasibility of long-range planning horizons, the benefits of wide-ranging community engagement, and the value of comprehensive 'holistic' planning for local community priorities extending beyond councils’ own responsibilities.

Influenced by the success of these voluntary strategic plans and by the broader influences we will discuss in the next section of this paper, the latter half of the 2000s saw the NSW Government revise its statutory planning framework for NSW local councils to include a mandatory (minimum 10-year) community strategic plan. The community strategic plan operates as part of an "integrated planning and reporting framework for NSW Local Governments" that is designed to make them "accountable for their actions” (NSWDLG 2006a; NSWLG Act 1993, ch. 13). It thus provides a clearer structure for councils wishing to undertake such planning. It also incorporates "social equity principles of equity, access, participation and rights" as one of its key drivers and in doing so, replaces the mandatory social plan that was previously required (NSWLG Act 1993, s. 402(3)(b); NSWDLG, 2006a; NSWDLG 2009d). As these community strategic plans are prepared and enacted over the next few years, they will become the highest level of plan that councils will prepare (NSWLG Act 1993, No. 30, ch. 13; NSWDLG 2009d). Within the new planning framework, they are to be supported in each council by a resourcing strategy "for the provision of the resources required to achieve the objectives established by the community strategic plan” (NSWDLG 2009d, p. 5), a 4-year 'delivery program', and an annual operational plan, so that the community's strategic goals are systematically translated into actions (NSWLG Act 1993, ch. 13; NSWDLG 2009d, p. 6; NSWDLG 2010, p. 11-23).

\footnotetext{
${ }^{6}$ Councillors are the elected representatives of local government in NSW. Local government elections are
} held every four years. 


\section{Influences}

A number of historical shifts created a policy environment supportive of the development of mandatory community strategic plans in NSW. Some are based on changes in theory and approaches in planning worldwide; others are specific changes in planning practice in the NSW local government context. We address five of these shifts. They range from the growth of participatory democracy within local government systems previously dominated by representative forms of democracy, through to the emergence of sustainability as an overarching concept which has increasingly refocused local government from the so-called 'three Rs' agenda - roads, rates and rubbish - to supporting the development of sustainable local communities (Brown 1997).

\section{Increasing citizen participation}

Throughout most of the twentieth century, citizen involvement in Australian local government, and in local government in many other Commonwealth countries, fell largely within the ambit of indirect participation; that is, "those legal activities by private citizens that are more or less directly aimed at influencing the selection of [their representatives] and/or the actions they take" (Aulich 2009:46). This indirect participation has often been further diluted as a result of structural changes in local government, such as the decline in the number of elected representatives per head of population (Hearfield \& Dollery 2009:73).

Since the 1960s, there has been a growing interest in increasing citizen participation in local government decision making and planning processes (Cook \& Morgan 1971). This has led to a search for better complementarities between representative and participatory democracy (Innes \& Booher 2004). As a result of this shift, there is now a significant body of political theory that argues for a more participatory model of democracy rather than a representative one that allows citizens to have a say only through elections (see Aulich 2009; Hearfield \& Dollery 2009). Proponents of participatory democracy argue that citizens have a right (and indeed should be encouraged and supported) to participate in a range of ways, on an ongoing basis, in decisions that affect them. Rights-based reasons for participation relate to the democratic right of citizens to have input into policy: "bringing the pattern of values and preferences represented within the policy process closer to that existing within society as a whole” (Rydin \& Pennington 2000:154); and focus on overcoming barriers to participation. Within this rationale, public participation is successful when it involves a wide range of parties, and works 
towards a shared vision or consensus, and therefore results in a plan, policy or decision which operates with a greater level of consent. There is an ever-increasing number of examples of governments at all levels in Australia that are attempting to provide new ways for citizens to participate in planning, decision making and policy. ${ }^{7}$

It is at the local government level that there is the most activity of this kind, with many councils engaging their communities in a wide range of planning and policy-making activities. Some councils go beyond statutory minimum notification or consultation requirements, and engage their communities in order to pursue additional objectives of trust building, community development, long-term visioning, better integration or community building (Prior 2007; Prior 2008). Key amongst these have been the community engagement processes that councils such as Blue Mountains City Council (BMCC, 2000b), Coffs Harbor City Council (CHCC 2009a, 2009b and 2009c), Cowra Shire Council (Cowra Shire Council 2006a and 2006b) and City of Sydney (COS) (COS n.d.) adopted for the preparation of voluntary long-term strategic plans prior to the NSWLG Act. ${ }^{8}$ The ability of councils to engage communities in planning and decision making processes is being supported by an increasing body of resource materials (see for example, DECC 2008; Carson \& Gelbar 2001), and the inclusion of community participation as good practice within local government policies and codes (Marshall \& Sproats 2000:502).

As noted earlier, much has been written in recent decades about the tension between representative and participative democracy at the local government level (Held 1996; Day 1997), about the weaknesses of each when they are applied separately, and about the need to combine them. For example, Somerville (2005) and Meadowcroft (2001) refer to the need for a balance between the two, and suggest that participatory democracy, like representative democracy, has its limits. An attempt to achieve this balance is evident within the legislation that guides the preparation of mandatory community strategic plans (NSWLG Act 1993).

\footnotetext{
${ }^{7}$ See for example the Western Australian Government's 2003 Dialogue with the city and other deliberative democratic processes that have been employed in Australia (Carson 2007)

8 The development of BMCC's voluntary 25-year strategic plan involved a wide range of community engagement activities, including creative arts processes and community festivals (BMCC 2000a, 2000b); Cowra's 30-year voluntary strategic plan (Cowra Shire Council 2006a) was created through a Future Search Conference in which 80 community members came together over three days to identify a vision and strategic directions; and the development of the voluntary Sustainable Sydney 2030 Strategy (CoS n.d.) was based on consultation with 12,000 local residents through roundtable discussions, community workshops, Live Green panel discussions, six forums with the Indigenous community, eight primary school workshops, and government briefings.
} 
The NSWLG Act requires local councils to prepare and implement a community engagement strategy to develop their community strategic plans so that local communities can be involved in important "discussions about funding priorities, service level, preserving local identity and to plan in partnership for a more sustainable future" (NSWDLG 2009e:2). At the same time, the legislation requires councillors, after each four-yearly election, to review and if necessary amend the existing plan or to develop a new one "to ensure that the area has a community strategic plan covering at least the next 10 years" (NSWLG Act 1993, s. 402 (5)), with the understanding that council is the custodian of the plan "for the local government area on behalf of their community" (NSWLG Act 1993, ch. 13, Introduction). Further extensive community engagement is required.

\section{Diversifying forms of knowledge}

Over the past few decades there has been numerous critiques of the way in which planning and decision-making processes in local government have been traditionally dominated by a 'top-down' approach, based on positivistic forms of expert knowledge (typically knowledge held by council officers as a result of professional training) (Frieden 1968; Merrifield \& Swyngedouw 1997). A broad range of hybrid approaches to planning were developed in the last decades of the $20^{\text {th }}$ century in response to these critiques (Sager 1994; Healey 1998).

A key feature of these new approaches is that they seek to take into account the voices of a diversity of players, rather than just those of expert planners, and to use the knowledge that emerges from these alternative sources to inform the planning process (Healey 1998). They also seek to capture diverse knowledge through dialogue with community; through learning to read symbolic and non-verbal evidence; and through contemplative or appreciative inquiry (Frieden 1968; Smith 1997). The purpose of planning thus becomes the handling of multiple 'knowledges'. ${ }^{9}$ The emphasis is on listening to unheard voices and hence previously unheard knowledges, variously categorized as lay, local, experiential or intuitive. The difficulty that this poses is how to handle the multiple sources of knowledge, how to engage different knowledges with each other, and how to make complementary changes to decision making. The answer that has generally emerged is for a greater reliance on deliberative and collaborative approaches such as:

\footnotetext{
${ }^{9}$ The term 'knowledges' in this context means the diversity of ways of knowing, or bodies of knowledge that can be brought together to inform a plan-making process (see Healy 1996, 1998)
} 
advocacy planning, equity planning, communicative planning and radical planning (e.g. Foster 1983; Sager 1994; Healey 1998).

These new approaches are often referred to as the communicative or pluralist turn in planning (Innes 1995) because they encourage a participatory approach emphasizing inclusive planning processes and highlighting the planner's role in mediating among stakeholders (Healey 1998; Habermas 1981). Increasingly, examples of such processes can be found amongst NSW local governments, such as Parramatta City Council and the City of Sydney. These councils have sought to develop processes based on the principle that community members are essential participants in developing knowledge about priorities and approaches to the delivery of services and projects, and the maintenance of infrastructure. In these processes, community members are actively engaged beyond a standard 'consultation on draft' approach (Prior 2007).

Reflecting this trend towards developing plans based on a broad range of knowledges, there is a requirement within the new community strategic plan legislation that councils ensure the plan is adequately informed by "relevant information relating to civic leadership, social, environmental and economic issues” (NSWLG Act 1993, s. 402 (3) (c)). This requirement raises questions about how to blend and balance expert knowledge with knowledge emerging from diverse community sources.

\section{Emergence of sustainability as a focus within local government}

Sustainability emerged as a key concern in local governance in the last decade of the 20th century. The idea of sustainability has led to a growing realization that achieving such goals as social inclusion, economic regeneration, environmental protection and the efficient delivery of services to communities involves an increased readiness to address issues holistically. This requires the introduction of mechanisms for more integrated forms of planning that actively seek community involvement (NSWDLG 1999; NSWDLG 2006a).

An important influence on community strategic planning in NSW is increasing concern in the local government sector about long-term financial sustainability. A study commissioned by the Local Government and Shires Associations (LGSA) in 2005 (the Allan Report), found that while NSW councils are generally low in debt levels (measured against asset levels), 25\% were considered "financially unsustainable” (NSROC 2010). 
Related issues include ageing infrastructure, limits to rate increases which are enforced by the state government ('rate pegging'), uncertainty about state and federal government funding, increased demands on the sector and 'cost shifting, ${ }^{10}$ by other levels of government. Two of the seven recommendations of a recent NSW infrastructure task force referred to the need for long-term asset management planning and financial planning (DLG 2006), stating:

Strategic long term asset management and financial plans be included as essential components of an integrated planning and reporting framework across NSW local government. (Recommendation 1)

and:

Legislative amendments requiring ten year financial planning be introduced into the Local Government Act 1993. (Recommendation 6).

Infrastructure maintenance is an issue at the heart of this problem - roads, drainage, parks and other community facilities are in many cases ageing and need major repair or replacement (see for example Sutherland Shire Council 2009). Allan (2008) suggests that NSW councils will need to implement huge increases in rates, fees and charges over the next ten years unless the commonwealth and/or state governments come to their assistance, or they drastically cut services, or they allow a backlog of dilapidated infrastructure to grow worse, or they accept escalating budget deficits.

In the face of these financial challenges, community strategic plans provide councils with a way to distinguish between the 'critical few' and the 'important many' community needs. They may also provide a sound foundation on which to approach other levels of government for funding or rate increases (through special levies) to pay for these priority items (see for example Hornsby Shire Council 2009). As Pears (2008) suggests:

By exploring its sustainability in terms of services, infrastructure and finances, a council can develop a business case for increased funding to put to its community and the Minister for Local Government.

Moves towards integrating environmental sustainability into local government decision making can be traced to the United Nations Conference on Environment and Development (UNCED) at Rio de Janeiro in 1992 (Gordon 1994). At the conference, Australia, along with other nations, agreed to Agenda 21 - an action plan implementing sustainable development principles. Chapter 28 of Agenda 21 subsequently evolved into Local Agenda 21 (LA21) which set out a new role for local government: formulating

${ }^{10}$ In 2003, a Federal Parliamentary inquiry (the Hawker Inquiry), suggested that the impact of cost shifting by the states onto local government was between $\$ 500$ million to $\$ 1$ billion per year (NSROC 2010). 
sustainable development strategies and integrating social, environmental and economic sustainability into mainstream policies (Cotter \& Hannan 1999; Gordon 1994). LA21 was firmly grasped by many local governments across Australia through the 1990s as a mechanism to improve quality of life through partnership working, coordinated action across sectors, and engaging local communities in forming a shared vision. The voluntary nature of such commitments meant they were susceptible to changing political priorities and resourcing constraints (Mercer \& Jotkowitz 2000). However, since 1999 local governments in NSW have had a legal obligation to consider sustainability in their decision making. Councils, councillors and council employees are required to have regard to the principles of ecologically sustainable development (ESD) in carrying out all of their responsibilities (NSWLG Act 1993, s. 7, 8, 403(2)).

A nationwide survey of Australian councils found that by 1994, councils generally recognized the need to combine social, economic, and environmental agendas in their planning and in their administrative structures (Brown 1997). Recent publications (see Holmes et al. 2008; Brackertz \& Meredyth 2008), forums for local government practitioners (see NSWDECC 2008) and programs (see Cuming \& Bragg 2006) focus on communicating the critical role of sustainability at the core of a council's governance responsibilities, and on helping councils better integrate these objectives into strategic planing and daily operations. Many councils have taken a strategic approach to planning for environmental protection or broader sustainability even though the framework for doing so has been emergent, voluntary and open to interpretation (see Herriman et al. 2008).

The shift towards local governance for sustainable communities is reflected in the new mandatory community strategic planning processes in NSW and the associated emerging framework for planning and reporting (Bibby 2009). The framework recognizes that "communities do not exist in isolation - they are part of a larger natural, social, economic and political environment that influences and, to a large extent, shapes their future direction” (NSWDLG 2009e, p. 2, see also NSWLG Act 1993, s. 402(3)(a)). This recognition means that plans must address "civic leadership, social, economic issues in an integrated manner” (NSWLG Act 1993, s. 402(3)(a)). 


\section{Addressing social justice and embedding social planning}

The fourth identifiable influence, closely linked with the first three, is the ongoing attempt to entrench the notion of social justice within local government decision making and planning processes. The notion of social justice - the idea that there should be justice in every aspect of society, rather than merely in the administration of law, and that individuals and groups are entitled to fair treatment and an impartial share of the benefits of society - emerged as a key aim of social planning in the Australian local government sector during the latter part of the 20th century (Menzies 1993:3; see also Menzies et al. 1996). As Menzies notes:

social planning should be underpinned by principles of social justice. This means that the social project should ... protect the interest of vulnerable groups ... avoid discriminatory practices ... consider the equity implications of proposals ... promote fair, open and participatory decision making ... and ensure equal opportunity in it practices (Menzies 1993:5).

Throughout the 1990s and 2000s, the focus of NSW local governments on social justice was strengthened through the development of social justice strategies and directives for all levels of Australian government (see Commonwealth of Australia 1992; NSW Government 1996; NSW Government 2000). As a result of these directives and strategies, social justice principles have been incorporated into the NSW charter of local government (section 8 of $N S W L G$ Act), and into 1998 legislation $^{11}$ that requires all councils in NSW to develop a social/community plan that addresses social justice issues. Also, in their annual reports councils are required to report on access and equity activities "that aim to promote social justice and enhance community wellbeing" (NSWDLG 2002, p. 7; Schwarz et al 2007).

The emergence of social sustainability as part of the broader concept of sustainability in the past two decades, whilst still nascent (McKenzie 2004:11; Koning 2001: 2), has added a new 'future focus' dimension to the notion of social justice - that is, of "a society that is just, equal, without social exclusion and with a decent quality of life, or livelihood, for all” (Koning 2001:9). As Partridge (2005:8) has noted: "the difference between social justice and social sustainability is the 'futures focus' that is contained within the sustainability perspective.” It follows that social sustainability requires not only the creation of a just society in the present, but also the establishment of structures

\footnotetext{
${ }^{11}$ See NSW Local Government (General) Amendment (Community and Social Plans) 1998; NSW Local Government Act (General) Regulation 1999.
} 
and processes that will guarantee lasting and continuing justice for current and future generations (see also Smith 1997).

A number of NSW councils have already sought to incorporate social justice initiatives into voluntary long-term strategic plans (see PCC 2005:6), and have noted the ineffectiveness of the four-year planning cycle to address issues such as neighborhood disadvantage that require longer-term investment by councils and their partners (Prior 2008). Building on these experiences, mandatory community strategic plans require the establishment of "strategic objectives together with strategies to achieve those objectives...based on...social justice principles of equity, access, participation and rights” (NSWDLG 2009e:6; see also NSWLG Act 1993, s. 402 (4); NSWDLG 2010). As well as requiring social justice principles to be embedded within community strategic plans, the Act also requires that social planning be embedded in the process (NSWDLG 2010:31) replacing the previous mandatory requirement for preparation of a social plan. We later explore the challenges faced by councils in attempting to achieve social justice through the community strategic plan.

\section{The trend towards longer-term, integrated decision making and planning}

The final influence we examine is the increasing realization in the second half of the $20^{\text {th }}$ century that there was a need for more integrated forms of planning within local government that broke down the departmental approach to planning - through the development of corporate planning, integrated planning and strategic planning. During the 1960s, a range of studies challenged the traditional departmentalism within local government and encouraged a shift towards a corporate approach to management and policy formulation (Redcliffe-Maud et al. 1969; Her Majesty's Stationery Office 1972). The corporate planning approach that emerged (Rugman 1973) sought to manage councils' resources to create a more 'integrated response to the present and future needs of its community' (Menzies et al. 1996:164; Menzies 1993:2). The reorganization of many councils that accompanied this approach (Boyd 1992) saw a greater emphasis on the need for staff and operating divisions to participate in more integrative forms of planning for the communities in their local government area (Kidd 2007; Healey 2005).

Australian has seen increasing attempts to create more integrated planning processes within local government such as the emergence in the 1990s of Integrated Local Area Planning (ILAP) which sought to create "a pathway to better local area government" 
(ALGA 1993:5; NSWDLG 2005). It was argued that an effective combination of strategic and corporate planning within council was central to ILAP: strategic planning was seen as being concerned with influencing trends and issues across all facets of local government areas, whilst corporate planning was defined as planning for the administration of the council's own activities within that broader context.

Whilst the requirement for corporate plans contained in the 1993 Act provided a foundation for more integrated forms of planning, dependence on relatively short-term management plans has come under increasing criticism throughout the early $21^{\text {st }}$ century. The Infrastructure Task Force (LGSA 2007), amongst others, noted the challenges of planning sustainable infrastructure within the 4-year election cycles of local government, and the three-yearly management planning cycle used by most councils. Following the Independent Inquiry into the Financial Sustainability of NSW Local Government $2006^{12}$ (Dollery \& Crase 2006), a need was identified for a planning horizon beyond three years to ensure longer-term financial and infrastructure issues were satisfactorily addressed. The new integrated planning and reporting framework for NSW local governments, in which the (minimum) 10-year community strategic plan is the principal document (NSWLG Act 1993, s. 402(1); NSWDLG 2006a; NSWDLG 2005), was introduced to address this need:

each local government area must have a community strategic plan developed by the council for the future of the local community covering a period of at least 10 years. To support the community strategic plan, a council must have a long-term resourcing strategy that includes long-term financial planning, workforce management planning and asset planning (NSWLG Act 1993, Ch. 13 Introduction).

In the next section, we explore the challenges that local governments of different sizes face as the custodians of this new planning framework.

\section{Challenges and Opportunities}

This section reflects on the recent experiences of several NSW councils that are in the process of creating, or have created, their community strategic plans. It identifies some of the challenges councils are likely to face in the plan-making process, and the opportunities that these challenges might bring.

\footnotetext{
${ }^{12}$ The four main goals of the inquiry were to: determine the current financial position and performance of the NSW local government sector; to gauge the adequacy of existing NSW local government physical infrastructure and service delivery; to assess the financial capacity of local government to meet its statutory obligations, expected functions and likely future challenges; and to identify possible financial, administrative, governance and intergovernmental reforms that could address any problems (Dollery \& Crase 2006).
} 


\section{The varying capacities of councils to implement community strategic plans}

Earlier in this paper, we examined the ongoing emergence of more integrated forms of planning and reporting within Australian local government and discussed community strategic planning as a part of this process. Concern has arisen within many NSW local councils about how they can effectively undertake the varied and complex processes and changes required under the new integrated planning and reporting framework (IPRF). These concerns are not evenly distributed amongst councils but are very much related to their size and geographical context.

A large majority of Australian local governments are non-urban - in 2005, 560 Australian local governments, or $78 \%$ of the total number, were classified as 'rural' or 'regional’ (DoTARS 2005:3 cited in Aulich 2009). This urban-rural divide represents a critical dimension of uneven resourcing (Aulich 2009:56). Similarly, the 152 local councils in NSW vary greatly in terms of their geographical reach, population and capacity. Populations range from 284,692 in Blacktown City to just 1,286 in Urana Shire (NSWDLG 2009b:14-16); geographical areas from 53,509km² (Central Darling Shire) to 5.7 km² (Hunters Hill) (NSWDLG 2009b:14-16); and numbers of staff from 1517 fulltime equivalent at the City of Sydney to just 32 at Urana Shire (NSWDLG 2009b:124126).

A recent review raised concerns about the ability of smaller and regional councils to engage with complex issues such as sustainability, which are core to the success of the community strategic planning process (Pillora et al. 2009:16). Smaller and isolated regional councils identified staffing, resourcing and capacity as key concerns, with comments such as: "we don't have anyone to do the work on council's own sustainability. Even if we have the information there is no one to act on it"; "staff have to take on responsibilities that they're not trained for and so mistakes get made. We're forever playing catch up”; and “[we] don’t have the resources to apply for and manage grant funding” (Pillora et al. 2009:16). While a phased roll-out of the new legislation ${ }^{13}$ allows smaller councils more time to come to terms with the IPRF, they may still face considerable resourcing constraints. As yet, the reforms have not been linked to any explicit and targeted state government funding streams to support the transition (LGMA 2009:7).

\footnotetext{
${ }^{13}$ Three phases of implementation are proposed. All councils will be required to comply with the new framework, and to have adopted a Community Strategic Plan, by 2012 (NSWDLG, 2009c)
} 
In the coming years, it is likely that these concerns will extend to a large majority of NSW councils, not just those that are small or isolated, given the ongoing widespread skills shortages in the NSW local government sector, especially in land-use planning (Red Letter Communication 2005:2 and 20). Also, in interviews with councils across NSW on sustainability responses, staff capacity and turnover has been raised as a significant barrier to progress (Pillora et al. 2009:14). It is likely that these same skills shortage issues will affect corporate planning in the future, as requirements increase in terms of the number of mandated plan outputs, the extension of the planning horizon, and the increased requirement for community engagement in the plan-making process.

The NSWDLG has announced that it is considering a number of strategies to support implementation of the IPRF, including:

- identifying councils who are doing well in particular aspects of the planning and reporting framework, and liaise with them about how their practice may be used to support councils who need further development in these areas; and

- providing feedback to councils during the initial implementation regarding how well they are meeting the statutory requirements of the new Integrated Planning and Reporting Framework (NSWDLG 2009a:12).

Councils have expressed an interest in "templates, check lists, standards and a resource library to assist with the transition" (LGMA 2009:6). It seems that these support measures will be critical to ensuring that opportunities for learning are maximized in the sector as individual councils may be too busy grappling with the changes required and feeling their way through their first community strategic plan process to initiate systematic information exchange. There will be an important role for state government and industry peak bodies to play in facilitating a sharing of approaches among councils, in a way that recognizes scale and capacity.

\section{The role of councils as custodians of community strategic plans}

The community strategic plan reflects the formalization of a previously voluntary form of strategic planning that emerged in many NSW local governments over recent decades. As the name implies, community strategic plans seek to give emphasis to community-led rather than council-led strategy development, the idea being that the plan is owned by the local community, developed through extensive input by the community, and is for the community / whole local government area. It is not developed by a single institution, 
even though one institution - the council - is required to help bring the plan into being and operates as its 'custodian'.

Thus whilst councils will become the custodians of the strategic plans developed for the communities they represent, they are not seen as wholly responsible for their implementation. They are encouraged to partner with community organizations and NSW government agencies to deliver the objectives set out in the plans (NSWDLG 2009d:5). This is in line with the approach of many councils who voluntarily developed long-term strategic plans based on extensive community input prior to the implementation of the new legislation. For example, when Cowra Shire Council in central NSW developed 'Futures 30', a 30-year strategic plan (Cowra Shire Council 2006a), it was "sponsored and facilitated by Cowra Shire Council but the plan belongs to the Cowra Community” (Cowra Shire Council 2006b). The plan includes a statement of council's role but also identifies the 'other players' (such as the NSW Government and NGOs) involved for each strategic objective (Cowra Shire Council 2006a).

What this new role of 'custodian' means in practice is twofold. Firstly, that local governments are transformed into facilitators of planning, which the community as a whole must carry out. As some councils have noted, this constitutes a transformation of local governments towards 'enabling' organizations, with a focus on being facilitators of community projects and social outcomes:

a funder and enabler of public services with the management and control of these projects devolved to the institutions of civil society ... a process, as a way of encouraging communities of interest and mutual forms of political action (Latham 2001, cited in McGrath et al. 2004:7).

Secondly, local governments are learning that the IPRF requires them to become regional brokers between other agencies and the community. Councils are now required to consider actions in their plans that they themselves cannot carry out, and that other agencies will need to deliver. This involves brokerage - lobbying other agencies to implement actions which will deliver on the communities' visions. A concern of many councils is that whilst they are required to broker arrangements with other agencies (such as departments of the NSW Government), those agencies do not have a reciprocal obligation to consider local community visions when shaping their own strategic commitments. 


\section{Engaging the community in strategic planning}

Over recent decades there has been a shift within NSW local governments to embracing greater participatory governance that actively engages communities in the formulation of policy (Aulich 2009). The new IPRF legislation, with its requirement for involving local communities in strategic agenda-setting through active two-way deliberation, provides a significant ongoing opportunity for embedding participatory governance within planning processes. Whilst many councils have seized this opportunity, it has also led to extensive discussion within local government on what it means to engage communities in strategic plan development; on councils' organizational capacity to support community engagement; and on the ability of councils to balance the new participatory dimensions of plan development with the traditional prerogative of elected representatives to devise plans and decide how they will be carried out.

Across NSW, the degree to which community engagement in strategic planning is a new challenge for local councils varies considerably, depending on past experience and capacity. ${ }^{14}$ For example, Blue Mountains City Council, as previously mentioned, has a history of developing long-term strategic plans (BMCC 2000b) through an extensive community participatory process, and has had time to develop and establish extensive mechanisms to support such processes (see also Gosford City Council 2005:11).

By contrast, Ashfield Council needed to develop engagement processes for their community strategic plans from scratch. In Ashfield's case, it was able to draw on substantial previous work undertaken to develop a Community Engagement Policy and a Community Engagement Toolkit (Ashfield Council 2008). These documents were based on the International Association of Public Participation (IAP2) principles and the Brisbane Declaration (Brisbane Declaration on Community Engagement 2005), and represented a clear commitment to embedding quality community engagement into council policy and practice.

Guided by the policy, a key focus of Ashfield Council was to explore how it could incorporate community consultation processes into existing activities, rather than seeing

\footnotetext{
14 A survey of 25 councils finds that municipalities with a population below 50,000 are much less likely to undertake community consultation (which, the authors suggest, may reflect general satisfaction with the elected members). In councils with populations above 50,000, they find little correlation between size and sophistication of consultative mechanisms. That is, councils with populations of 50,000 are just as likely to consult the public as those above 150,000. The authors also note that some of those with the largest populations did the least consulting (Marshall \& Sproats 2000:501-502).
} 
them as a collection of one-off and stand-alone activities which required additional resourcing and funding. It thus sought to balance council's capacity with the ideals expressed in the new legislation. Ashfield Council's response to the problem is evidence of an awareness that designing and managing significant community engagement processes not only demands a substantial time commitment by council staff, but also requires specific skill sets in these staff - skills that may not have previously been identified as important in roles which were traditionally focused on technical or contract management tasks (Jones 2002).

Other authors have noted that participatory approaches may require institutional change within government agencies (McGrath et al. 2004), and that hands-on facilitated training and reflective field experience of participatory processes may be required for senior managers and large numbers of agency staff (Korten 1988, cited in McGrath et al. 2004).

As previously indicated, another key issue for local government in the community strategic plan-making process is that direct community participation is given a legislative foundation (NSWDLG 2009d:6) but this does not extinguish the legitimate powers of elected representatives to direct / determine the final content of the plan. This has resulted in discussion about what constitutes a desirable balance between representative and participatory democracy in the creation of community strategic plans. A key question that has arisen within many councils is the extent to which elected representatives should be involved in the engagement process. How do elected representatives make sure they don't inappropriately influence the development of the strategic plan? What is the appropriate relationship between the other participants in the planning process, and the information they provide, and those who retain formal responsibility for making decisions in council about the final form of the plan?

All councils will need to carefully consider the aims of their engagement processes (where they sit in the IAP2 spectrum, for example), what it is they are asking the community, how they define 'community', and what consultation methods they might use. They will also need to decide precisely how the results of the engagement process will inform planning and decision-making, and what the relationship will be between the engagement process and the formal decision-making responsibilities of council. This may be another area where institutional support for capacity building is required. As Aulich suggests, “Given current constraints on local government's autonomy and 
resources, in many cases, effective moves towards participatory governance may need leadership and support from outside” (Aulich 2009:57).

\section{Balancing top-down versus bottom-up knowledge}

The emergence of community strategic planning in NSW local government presents a new opportunity for local councils to explore ways in which relevant forms of information / knowledge from both top-down sources (such as the Australian Bureau of Statistics) and bottom-up sources (such as local knowledge emerging from the community engagement process) can be blended to create optimal planning instruments.

This joining together of top-down and bottom-up knowledge has been referred to as a potential black box by several local councils. The phrase reflects concern and uncertainty as to how knowledges collected during the plan-making process are used and merged; what is potentially lost during that merger; and the potential for misinterpretations and unwarranted exclusion of some inputs. These concerns stem from the question of how to determine the relative significance and weight to be allocated to varied and specific knowledges amid the plethora of data generated in such processes. For example, in instances of dispute between different knowledges, it is never clear whether the tacit/experiential knowledge of the local community is to be privileged over the formal knowledge of planning experts, or vice versa. What has emerged from these concerns is a desire, on the part of at least one metropolitan local council (Ashfield), to develop a series of principles and analytical frameworks for constructing a coherent synthesis.

These principles and frameworks ranged from the simple idea of acknowledging that all types of knowledge ${ }^{15}$ need to be valued and taken into account, through to using a planning approach that favors the importance of workshop and engagement events that promote the 'co-construction' of knowledge amongst multiple participants. In this way, participants can be engaged in the negotiation and merging of knowledges. This would require a shift from simple information collection from individuals by experts (as an 'input' to expert-led planning) to 'negotiated knowledge' generated through collective learning and deliberative processes, that can better arbitrate amongst diverse claims and priorities.

\footnotetext{
${ }^{15}$ Whilst the council attempted to value all forms of knowledge within the process, it is important to note that local governance contains a complex and intersecting mixture of normative precepts (e.g. protection of human rights, equality, and liberty to produce and consume amongst others) which inevitably restrict the types of knowledges that can be considered.
} 
The ultimate aim of this approach to knowledge development within the plan-making process is to be concerned not with comparing the values of fixed knowledges, but with facilitating the negotiation of emergent knowledges. Thus Ashfield created a process that was focused on a range of events - large community meetings through to councillors talking to individual community members - using a conversational structure and allowing collective knowledges and negotiated knowledges to emerge. This process was branded 'Ashfield’s biggest conversation' (Ashfield Council 2009a), and allowed blending and dialogue between top-down knowledge and bottom-up knowledge. Topdown knowledge has often been criticized for embodying a 'provider led' approach that could, intentionally or otherwise, take power, control of resources and decision-making away from the community; whilst and bottom-up knowledge has been criticized for being 'patchy' in the localities and issues that it champions, and for having a tendency to come from unrepresentative individuals and factions within the community (despite attempts to proactively engage with a broad cross-section).

Whilst councils such as Ashfield have attempted to make the processing of knowledge emergence and negotiation explicit to all involved, they acknowledge that such an ideal form of knowledge gathering and processing is not always possible (due, for example, to the varying capacities and abilities of some elements of communities to engage in such mechanisms). Consequently, most councils still also use methods for collecting individual knowledges (e.g. through surveys, interviews and feed-back forms).

Another area that requires attention is the balancing of top-down strategic commitments and bottom-up identification of needs. The notion of a community strategic plan based around a locally generated vision for the future implies that communities have a significant degree of autonomy in determining their own direction. In reality the legislative requirements (LG Act 1993s402 (3) (d)) for community strategic plans require a measure of alignment of those plans with state government strategies and other planning instruments (such as regional land use plans). This raises questions about the true extent of community and council autonomy in establishing a local vision and strategies.

\section{Monitoring and evaluating the community strategic plan}

In the same way that each council has a 'custodial' role in developing the community strategic plan, the legislation prescribes that councils also have a custodial role in: 
monitoring the community strategic plan for the local government area on behalf of their community (NSWLG Act 1993, ch. 13, introduction).

And to that end:

The Community Strategic Plan must identify assessment methods for determining whether the objectives are being achieved (NSWDLG 2010: 10).

In addition, the specific requirements for reporting on the plan's implementation (beyond those for annual reports) state that:
the Community Strategic Plan must be reviewed every four years. ... A report on the progress on implementation of the Community Strategic Plan must be presented at the final meeting of an outgoing council. The review must include...a report from the outgoing council on the implementation and effectiveness of the Community Strategic Plan in achieving its social, environmental, economic and civic leadership objectives over the past four years (NSWDLG 2010:10).

Also:

The annual report in the year of the ordinary election must include a report (State of the Environment Report) as to the state of the environment in the local government area in relation to the objectives for the environment established by the Community Strategic Plan (NSWDLG 2010:23).

Monitoring the community strategic plan requires a shift on the part of councils from primarily monitoring service delivery and expenditure (as in the case of annual reports) to monitoring the movement of the community towards its long-term vision and goals. This shift has raised a series of interlinked questions: What should be included within this monitoring? Will the new plans be assessed? Will it be according to their own objectives, their degree of alignment with the council's operational activities, how effectively they meet the strategic plan directions, or how transparently they communicate with their communities?

One of the obvious challenges associated with this shift is which indicators or methods of evaluating performance to use. They need to evaluate the implementation of a long-term plan whose focus is the entire local government area, including domains of responsibility beyond councils and actions taken by other agencies. An associated challenge is that of linking information back to decision making - knowing how to respond to the monitoring data about the state of the local government area.

A recent review of councils' capacities to engage with sustainability issues highlighted inadequate systems for managing information as a key barrier to reflective practice and adaptive management. The review noted that: 
even for councils with the right motivation and a range of good programs, there were challenges with putting in place systems that would best support their efforts and help with the planning, promotion, and monitoring of education initiatives (Pillora et al. 2009:14).

These same challenges are likely to be present for councils engaging in a transition to monitoring outcomes under the IPRF.

State of the Environment reporting has existed as a mandatory part of the planning and reporting framework for local government in NSW since 1993; at first as an annual requirement (as an adjunct to the annual report) and from 1997 on the basis of comprehensive reports every four years and 'supplementary' reports in others. This requirement formalized councils' obligations to consider and report publicly about impacts on, and management of, the local environment, under a prescribed framework. State of the Environment reporting in NSW has had a varied implementation record (see for example Kelly 2007), not least due to concerns about weak linkages to management (corporate) planning. Nonetheless, the retention of this element in the new IPRF (for a summary of requirements see LGSA 2010) allays concerns about how councils might otherwise be encouraged to continue to collect time series data on the environment, to report on this publicly, and to retain a strong focus on environmental management and outcomes.

State of the Environment reporting typically contains indicators beyond service delivery (that is beyond simply 'response' in the pressure-state-response model ${ }^{16}$ and features ‘state' or 'pressure' indicators for local government areas (for example, coverage of remnant vegetation, stream water quality, or household greenhouse gas emissions). Similarly, reporting in relation to the community strategic plan requires 'community' level indicators. This means that in relation to the environmental outcomes of community-level planning, a range of indicators and data sets may already exist, and there may even be existing community-based monitoring efforts.

One way of developing the community-level indicators needed for the new IPRF is to draw on established community wellbeing frameworks which exist internationally and in Australia. These frameworks are usually integrated maps of key community priorities that show progress in areas of concern to local communities and how different issues fit

\footnotetext{
${ }^{16}$ For more information on the PSR model see OECD 1993
} 
together (Partridge \& West 2010). They can help local councils to measure and monitor selected features of the local community, and track progress at the local scale. Used in this way, they can be a powerful tool to support an integrated or 'triple bottom line' approach to policy development, program implementation and evaluation (Wiseman et al. 2006).

Community indicators can also assist with strategic planning goals by engaging stakeholders in local governance processes, and play an important role in keeping local governments accountable to their communities (Salvaris 1997). At the very least, this accountability applies to those issues for which councils have direct responsibility - but in a more general sense, community indicators can help councils to better understand their communities' needs and priorities, and inform less direct action by councils, such as advocacy or lobbying of other organizations (Partridge \& West 2010). Community wellbeing indicators can also help ensure that the decisions councils make about policies and budgets are based on the best local evidence, both of community priorities and of the key social, economic, environmental, cultural and governance trends in their localities (Davern et al. in press).

A related challenge for community-level monitoring and reporting is the need for statistically reliable indicators and data, including indicators that are useful in a policy context and provide strong links to decision-making processes (Holden 2009; Dluhy and Schwarz et al; 2006). Without these, monitoring may well produce data that has no real bearing on communities and little impact on planning and resource allocations for their future wellbeing (Holden 2009).

An opportunity exists to draw on the experiences of councils who have already progressed along this pathway (for example, the Blue Mountains City Council's emerging State of the City reporting framework), and for the NSW state government to provide useful examples and guidelines to councils about what might work well. The existence of some early industry-led peer-learning groups (especially the corporate planning group of Local Government Managers Australia (NSW)), and formal training providers (including the Local Government and Shires Association (LGSA) and the Centre for Local Government at the University of Technology, Sydney), will also provide useful forums for sharing approaches and models for successful monitoring. 


\section{Embedding social planning and social justice within the community strategic plan}

Considerable interest has emerged around the challenges and opportunities that stem from embedding social planning and social justice into the new IPRF and community strategic plans. As noted earlier, this integration of social planning and social justice into community strategic plans is particularly important given that separate social plans are no longer mandatory. There is a concern that councils' focus on social services, assets and identification of community needs will diminish.

Recently a survey was conducted with 64 social planners in NSW (Prior and Partridge 2009) into the social planning challenges faced by NSW local government. Unreferenced quotations within this section of the paper are drawn from this survey. Two thirds of the respondents worked on social planning in local government; the remaining third worked in a private company or consultancy. The majority of respondents (63.5 per cent; 33 of 52) indicated that the scope and understanding of social planning had changed over recent years. Embedding social planning within the new IPRF was identified as one of a series of key challenges and opportunities for local government in the coming decade.

Whilst the IPRF was generally understood as an opportunity to plan for long-term 'intergenerational' social justice, concerns were raised about how to engage communities in strategic thinking about social justice issues (see Prior \& Partridge 2009). These concerns included how to develop a community strategic planning process that supports community understanding and engagement with long term and short term social justice issues that emerge from financial crisis/recession, climate change/sea level rises, exponential population growth and the pressure on limited housing, health, food, energy and transport resources. As several planners noted, addressing such tensions may require planning strategies, not only to address issues of social justice, but also to inform "communities [that] they may not be able to live in a certain place (regardless of where they live), or continue to be supplied with the services they currently expect”. Also: "social justice for some time has [often been perceived to mean bringing] people up to a certain level, in the future it may mean that some people may have to lower their lifestyle so that others can have a more equitable access to resources".

One respondent noted that the community strategic planning process presents both an opportunity and a challenge to engage local communities in "collective thinking about how to pursue [local and community] sustainability and leverage greater commitment to social benefits” at the same time as acknowledging that local strategic decisions on these 
issues can no longer be thought of as outside of the broader global and regional systems on which these local strategic systems are embedded and depend.

The IPRF was seen by many respondents as an opportunity to strengthen the recent shift of social planning into the strategic planning domain and to ensure their practices and service provision are more socially sustainable. Social planning is [currently often] seen as a low level, detailed community activity, whereas the new integrated planning framework with its emphasis on community focused strategic planning that is based about such principles as equity, gives social planning the opportunity to be successfully elevated to a high level strategic, corporate activity. It will enable community/social planning to be placed as a critical and core element in New South Wales local government...as a change driver and motivator around which other strategic planning decisions should be made. Thus it was seen that the new integrated planning framework creates opportunities to consider the social impacts of councils' wider planning and to better integrate social planning at both the strategic and operational levels with environmental, land-use and economic planning.

Whilst the integration of social planning into community strategic plans was seen as an opportunity by many, it was also seen as a challenge, given that some local councils who currently “don't value social planning might use the integrated planning process associated with community strategic plans to devalue the role of expert social planners by dispersing social planning functions, allowing planners from other backgrounds claiming social planning expertise without appropriate training”. Many respondents were also concerned about the ability of the community strategic plan to effectively replace all aspects of the previously mandatory social plan, and a number of councils have decided to retain a separate, non-mandatory social plan.

\section{Conclusions}

This paper has traced the emergence of community strategic planning within the NSW local government context. In so doing it has provided insight into its influences and some of the challenges and opportunities which NSW councils face as they begin to implement processes for the development of their strategic plans. As indicated at the beginning of the paper, the influences, challenges and opportunities discussed are by no means a comprehensive list. 
The challenges and opportunities presented are necessarily open-ended given that local councils in NSW are in the early years of developing their community strategic plans. What this paper provides is an understanding of the depth at which many local councils are engaging with the process, and the extent to which they are seeking to: engage with a new role as custodian rather than plan-maker; determine how best to integrate community knowledge with expert knowledge; address questions of resourcing and capacity to make the transition to the new framework; maintain a strong environmental and social justice focus in the planning process and planning outcomes; and monitor and evaluate the implementation of their plans in a way which links to decision making.

In conclusion, it is worth noting that the ability of local councils in NSW to effectively develop community strategic plans depends in large part on a recurrent point raised throughout this paper: the relationship between the state government and local governments in implementing the new framework, and what roles the state government intends to play in supporting/regulating/overseeing/guiding councils in their implementation journey. Opportunities abound to share resources, to transfer knowledge and ideas through networks of councils and to disseminate successful approaches. In all of these transactions, the NSW government can play a strong supportive role. Defining how best to facilitate and support local governments' transition to community strategic planning will involve some important decisions about resourcing, support, guidance and oversight.

\section{References}

ALGA 1993, Making the connections: a guide to integrated local area planning, Australian Local Government Association, Sydney.

Allan, P, 2008, 'Financial sustainability remains biggest challenge for Councils'. Media Release. Accessed 10 October 2010 $<$ http://www.reviewtoday.com.au/080729_RT_Media_Release_re_FS_2008_study.pdf>.

Ashfield Council 2008, Community Engagement Policy, Sydney. Accessed 15 May 2010 $<$ http://www.ashfield.nsw.gov.au/files//your_council/have_your_say/community_enga gement_policy.pdf $>$.

Ashfield Council 2009a, Ashfield's biggest conversation: project overview, Sydney. Accessed 29 July 2010 $<\underline{\text { http://www.ashfield.nsw.gov.au/files//your_council/have_your_say/biggest_conversat }}$ ion/amc_abc_signage_a4 intro.pdf>.

Aulich, C 2009, 'From citizen participation to participatory governance in Australian Local Government', Commonwealth Journal of Local Governance, issue 2, January 2009, pp. 44-60.

Berry, A and Dillon, R 2005, Blue Mountains - our future. How we did it, Blue Mountains City Council.

Bibby, P 2009, 'Screws put on council spending', The Sun Herald, 10 May, p. 15. 
Blumer, H and Burgess, E (eds) 1935, Human side of social planning, American Sociological Society, Chicago, Ill., USA.

Brady, K 2007, ‘Auditor-General’s Overview: Matters arising from the 2006-16 Long-Term Council Community Plans’. Accessed 16 October 2010 <http://www.oag.govt.nz/localgovt/ltccp>.

BMCC 2000a, Management plan 2000-2001. Blue Mountains City Council, NSW.

BMCC 2000b, Towards a more sustainable Blue Mountains - a 25 year vision for the ity, Blue Mountains City Council, NSW.

BMCC n.d., Towards a more sustainable future - a map for action - 2000-2025, Blue Mountains City Council, NSW. Accessed 10 October 2010 < http://www.sustainablebluemountains.net.au/our-city-vision/>.

Boyd, L 1992, Planning for results: manual for Local Government on corporate planning, Municipal Association of Victoria, Melbourne.

Brackertz, N and Meredyth, D 2008, Social inclusion of the hard to reach: community consultation and the hard to reach: local government, social profiling and civic infrastructure: final report, Swineburne University of Technology, Hawthorn, VIC.

Brisbane Declaration on Community Engagement 2005, Adopted at the first International Conference on Engaging Communities, August 2005, Brisbane.

Bromely, R 2003, 'Social planning: past, present and future', Journal of International Development, vol. 15, issue 7, October 2003, pp. 819-830.

Brown, VA 1997, Management for local sustainability: policy, problem-solving, practice and place. National Office of Local Government, Canberra.

Burch, HA 1996, Basic social policy and planning: strategies and practice methods, Haworth Press, New York.

Burgess, E 1935, 'Social planning and the mores', in H Blumer and E Burgess (eds), Human side of social planning, American Sociological Society, Chicago, Ill, USA, pp. 1-18.

Carson, L 2007, An inventory of democratic deliberative processes in Australia: Early finding. An early finding from a report of three decades of deliberative designs in Australia, Website. Accessed 13 January 2010 <http://www.activedemocracy.net>.

Carson, L and Gelber, K 2001, Ideas for community consultation: a discussion on principles and procedures for making consultation work, prepared for the NSW Department of Urban Affairs and Planning, Sydney.

COS 2006, City of Sydney strategic plan 2006-2009, City of Sydney, NSW.

COS n.d., Sustainable Sydney 2030, Website. Accessed 13 January 2010 <http://www.cityofsydney.nsw.gov.au/2030/Default.asp>.

Cook, TE \& Morgan, PM 1971, Participatory democracy. San Francisco, Canfield Press.

Commonwealth of Australia 1992, Social justice strategy, Canberra, Commonwealth of Australia.

Cotter, B \& Hannan, K 1999, Our community our future: a guide to Local Agenda 21, Canberra, Commonwealth of Australia.

Cowra Shire Council 2006a, Futures 30 - a strategic plan for Cowra 2006-2036. Adopted by Council 24th July 2006. Accessed 14 February 2010

< http://www.cowraregion.com.au/home/2199/Strategic_plan.pdf>.

Cowra Shire Council 2006b, Futures 30, Website. Accessed 14 February 2010 <http://www.cowraregion.com.au/home/?id=2199 $>$.

Coffs Harbour City Council 2009a, Coffs Harbour 2030 plan, Adopted December 2009. Accessed 15 January 2009

$<$ http://www.wollondilly.nsw.gov.au/files/21289/File/communitystrategicplanfinal.pdf $>$. 
Coffs Harbour City Council 2009b, 2030 community ideas booklet. Accessed 15 January 2009 $<$ http://www.coffsharbour.nsw.gov.au/resources/documents/2030_community_ideas_b ooket.pdf $>$.

Coffs Harbour City Council 2009c, Community vision 2030. Accessed 10 October 2010 <http://www.coffsharbour.nsw.gov.au/www/html/3247-coffs-harbour-2030.asp>.

Cuming, P and Bragg, E 2006, The sustainability healthcheck, Developed by Sustainable Futures Australia (SFA) for Local Government Managers Australia, NSW (LGMA) and Department of Environment and Conservation NSW (DEC). August 2006.

Davern, M., West, S., Bodenham, S., \& Wiseman, J. Community Indicators in Action: Using Indicators as a Tool for planning and Evaluating the health and Wellbeing of a Community. (In Press).

Dluhy, M \& Swartz, N 2006, 'Connecting knowledge and policy: the promise of community indicators in the United States', Social Indicators Research, vol. 79, issue 1, p. 1 - 23.

Dollery, B and Crase, L 2006, A comparative perspective on financial sustainability in Australian Local Government, Working Paper 01-2006, September 2006, Brian Dollery, (ed.), Centre for Local Government, University of New England.

Dyckman, J 1966, 'Social planning, social planners and the planned societies', Journal of the American Planning Association, vol. 32, issue 2, p. 66 - 76.

Frieden, BJ 1968, ‘Towards equility of urban opportunity’, in BJ Frieden \& R Morris (eds), Urban Planning and Social Policy, pp. 313 - 334, New York, Basic Books.

Gordon, J 1994, 'Letting the genie out: local government and the UNCED', in C. Thomas, (ed.), Rio: Unraveling the Consequences, pp. 137 - 55, Frank Cass, London.

Gosford City Council 2005, Gosford vision 2025: a strategic direction for the future. Accessed 10 October $2010<\underline{\text { http://www.gosford.nsw.gov.au/customer/document_gallery/vision- }}$ 2025/vision-2025.pdf $>$.

Green, GP, Haines, A and Halebsky, S 2000, Building our future: a guide to community visioning, Madison, WI, University of Wisconsin - Extension, Report No. G3708.

$<$ http://www1.uwex.edu/ces/pubs/pdf/G3708.PDF>.

Habermas, J 1981, The theory of communicative action London, Beacon Press.

Healey, P 1998, 'Building institutional capacity through collaborative approaches to urban planning', Environment and Planning A, vol. 30, issue 15, p. 31 - 46.

Healey, P 2005, 'On the project of 'institutional transformation' in the planning field: commentary on the contributions', Planning Theory, vol. 4, issue 3, p. 301 - 310.

Hearfield, C \& Dollery, B 2009, 'Representative democracy in Australian local government', Commonwealth Journal of Local Governance, issue 2, January 2009, pp. 61 - 75.

Held, D 1996, Models of democracy, Oxford, Blackwell Publishers.

Herriman, J, Partridge, EY \& Paddon, M 2008, 'Planning for sustainability in NSW local government: practice note’, Commonwealth Journal of Local Governance, vol. 1, no. 1, pp. 1 - 9.

Her Majesty's Stationery Office 1972, Bains report: the new local authorities: management and structure. London, Her Majesty's Stationery Office.

Holden, M 2009, 'Community interests and indicator system success', Social Indicators Research, vol. 92, p. 429 - 448.

Holmes, G, Buchhorn, M, Wilson, S and Donovan, D 2008, The guide to good governance and ESD for local Councillors, Hunter and Central Coast Regional Environmental Management Strategy (HCCREMS), NSW.

Hornsby Shire Council 2009, Media Advertisements Proposed Infrastructure Levy. Accessed 10 October 2010

<http://www.hornsby.nsw.gov.au/uploads/documents/MediaadvertisementsProposedInfrastructureLevy.pdf $>$. 
Innes, J 1995, 'Planning theory’s emerging paradigm: communicative action and interactive practice', Journal of Planning Education and Research, vol. 14, issue 3, p. 183 - 189.

Innes, J \& Booher, D 2004, 'Reframing public participation: strategies for the 21st century', Planning Theory and Practice, vol. 5, issue 4, p. 419 - 436.

Jones, R 2002, 'With a little help from my friends: managing public participation in local government', Public Money and Management, vol. 22, issue 2, 2002, p. 31 - 36.

Kelly, A 2007, Management Plans and State of Environment Reports Prepared and implemented by Local Councils in NSW: Problems and Potential for Biodiversity Conservation. Centre of Local Government. < http://www.clg.uts.edu.au/pdfs/Kelly2007.pdf>.

Kidd, S 2007, 'Towards a framework of integration in spatial planning: an exploration from a health perspective', Planning Theory and Practice, vol. 8, issue 2, p. 161 - 181.

Koning, J 2001, Social sustainability in a globalizing world: context, theory and methodology explored, Tilburg University, The Netherlands, paper prepared for the UNESCO / MOST meeting, 22-23 November 2001, The Hague, Netherlands. Accessed 10 October 2010 <http://www.tilburguniversity.nl/globus/seminars/sem02.02.pdf $>$.

LGMA 2009, Capacity building for Local Government Professionals in NSW to deliver the Department of Local Government's integrated planning and reporting package, Findings from the June 2009 Local Government Managers Australia NSW and Department of Local Government Integrated Planning and Reporting Forum.

LGSA 2007, LGSA positions on the recommendations of the Local Government Inquiry, 5 July 2007. Accessed 10 October 2010 <http://www.lgsaplus.net.au/resources/documents/slg-lgsa-positions-table-on-lgi-recoms_0507072.pdf>.

LGSA 2010, State of the Environment Reporting. Accessed 4 October 2010 <http://www.lgsa.org.au/www/html/255-state-of-the-environment-reporting.asp>.

Marshall, N and Sproats, K 2000, 'Using strategic management practices to promote participatory democracy in Australian local government', Urban Policy and Research, vol. 18, issue 4, 2000, p. $495-514$.

McGrath, N, Armstrong, R, and Marinova, D 2004, 'Participatory development for regional sustainability in Western Australia: an enabling state?' Local Environment, vol. 9, issue 6, December 2004, p. $561-574$.

McKenzie, S 2004, 'Social sustainability: towards some definitions', Hawke Research Institute Working Paper Series No 27, University of South Australia, Magill, South Australia.

Meadowcroft, J 2001, 'Community politics, representation and the limits of deliberative democracy‘, Local Government Studies, vol. 27, issue 3, p. 25 - 42.

Menzies, C 1993, Ground rules: a social planning handbook for Local Government, Prepared for New South Wales Department of Planning, Local Government Association of New South Wales, Shires Association of New South Wales, \& New South Wales Local Government Industry Training Committee, Sydney, Local Government Association of NSW.

Menzies, C, Rogan, B, Heywood, P, \& Nivison-Smith, I 1996, Social planning guidlines for Queensland Local Government, Fortitude Valley, Queensland, Local Government Association of Queensland.

Mercer, D \& Jotkowitz, B 2000, 'Local Agenda 21 and barriers to sustainability at the local government level in Victoria, Australia’, Australian Geographer, vol. 31, no. 2, pp. 163 $-181$.

NSROC 2010, Modernisation of Local Government in NSW NSROC Discussion Paper - 2010. Accessed 10 October 2010 <http://www.nsroc.org/NSROC\%20Modernisation\%20Discussion\%20Paper\%2024\%2 0June\%202010.pdf $>$.

NSWDECC 2008, Integrating sustainability in local government - what are the implications for governance, strategy and practice? Symposium 24 and 25 November 2008, Milsons 
Point, Department of Environment and Climate Change, NSW Environment Trust and Our Environment: It's a Living Thing.

NSWDLG 1999, Environmental guidelines for State of the Environment reporting by Local Government. promoting Ecologically Sustainable Development, Sydney, New South Wales Department of Local Government.

NSWDLG 2002, Social / community planning and reporting guidelines Sydney, New South Wales Department of Local Government.

NSWDLG 2005, Fitting the pieces together: integrated planning and reporting by NSW Local Councils, Sydney, New South Wales Department of Local Government.

NSWDLG 2006a, Planning a sustainable future: a Department of Local Government options paper on intergrated planning and reporting for NSW Local Government, New South Wales Department of Local Government.

<http://www.dlg.nsw.gov.au/Files/Information/Integrated\%20Planning.pdf $>$.

NSWDLG 2006b, A new direction for Local Government position paper, Accessed 10 June 2010 $<$ http://www.dlg.nsw.gov.au/dlg/dlghome/documents/Information/Position\%20Paper.p $\underline{\mathrm{df}}>$.

NSWDLG, 2006c, Asset Management Planning for NSW Local Government. A Department of Local Government Position Paper. Accessed 10 October 2010

$<$ http://www.lgsa.org.au/resources/documents/slg-dlg-asset-management-planningposition-paper_0507.pdf $>$.

NSWDLG 2009a, Integrated planning and reporting framework: frequently asked questions and their nswers. Accessed 10 October 2010

$<$ http://www.dlg.nsw.gov.au/dlg/dlghome/documents/Information/Integrated\%20planni ng\%20and\%20reporting\%20Framework\%20-\%20FAQ.pdf>.

NSWDLG 2009b, Comparative information on NSW Local Government Councils 2007/08.

Accessed 10 June 2010

<http://www.dlg.nsw.gov.au/dlg/dlghome/documents/Comparatives/Comparatives 200 7 08.pdf $>$.

NSWDLG 2009c, Circular to Councils. Accessed 10 June 2010

<www.dlg.nsw.gov.au/dlg/dlghome/documents/Circulars/09-37.pdf $>$.

NSWDLG 2009d, Consultation draft: Local Government amendment (planning and reporting) Bill 2009: explanatory note. Accessed 10 June 2010 <http://www.legislation.nsw.gov.au/exposure/b2008-076-d08.pdf $>$.

NSWDLG 2009e, Planning a sustainable future: planning and reporting guidelines for Local Government in NSW: draft for public comment. Accessed 10 June 2010

$<$ http://www.dlg.nsw.gov.au/Files/Information/Draft\%20Planning\%20and\%20Reportin g\%20Guidelines\%20for\%20local\%20government\%20in\%20NSW.pdf>.

NSWDLG 2010, Planning a sustainable future: guidelines. planning and reporting guidelines for Local Government in NSW: version 1, NSW Division of Local Government and Department of Premier and Cabinet. Accessed 10 October 2010

$<$ http://www.dlg.nsw.gov.au/dlg/dlghome/Documents/Information/IPRGuidelinesJanua ry2010.pdf $>$.

NSW Government 1996, NSW social justice directions statement: fair go, fair share, fair say, Sydney, NSW Government.

NSW Government 2000, NSW social justice directions statement: supporting people and strengthening communities, Sydney, NSW Government.

OECD 1993, OECD Core Set of Indicators for Environmental Performance Review. A synthesis report on the Group on the State of the Environment. Enviroenment Monographs No.83. Paris.

Partridge, EY 2005, 'Social sustainability: useful theoretical framework?', in Conference Papers APSA 2005, Murphy M (ed.), Australasian Political Studies Association, ANU, Dunedin, New Zealand, September 2005, pp. 1-15. 
Partridge, E \& West, S 2010, Community indicator framework, Second draft report for City of Sydney, July 2010, Prepared by the Institute for Sustainable Futures, UTS and the Connerghy Centre, University of Melbourne.

PCC 2005, Penrith City Council strategic plan, 2005-2009, Penrith City Council, Sydney.

Pillora, S, Blackburn, N and Artist, S 2009, Barriers and drivers to sustainability in Local Government, Prepared for the Urban Sustainability Support Alliance by the Institute for Sustainable Futures, UTS.

Prior, J 2007, Innovations and transformations in urban governance: an analysis of local action planning initiatives within Penrith City and the City of Sydney, State of Australian Cities Conference 2007, Adelaide.

Prior, J 2008, 'The role of local government in redressing neighbourhood disadvantage: a case study from Penrith City Council', Commonwealth Journal of Local Governance, vol. 1, no. 1. <http://epress.lib.uts.edu.au/ojs/index.php/cjlg/article/view/767/745>.

Prior, J \& Partridge, EY 2009, 'Practitioners' views on the past, present and future of social planning in Australia', in State of Australian Cities (SOAC) Conference, Perth, Australia, November 2009, pp. 1-18.

Red Letter Communication 2005, Survey of skills shortages in NSW Local Government, Prepared for the NSW Department of Local Government on behalf of the Training and Professional Skills Shortages Taskforce. Accessed 10 October 2010 <http://www.dlg.nsw.gov.au/Files/Information/SkillsShortages.pdf $>$.

Redcliffe-Maud, J, Bolton, JE, Senior, D, Hill, J, Feather, V, Marshall, AH, Mursell, P, Longland, JL, Wallis, RC, Smith, TD and Sharp, EA 1969, Redcliffe-Maud report: Royal Commission on Local Government in England 1966-1969, London, Her Majesty's Stationery Office.

Rugman, CA 1973, 'Corporate planning in local government', Long Range Planning, vol. 6, issue 3, p. 17 - 21.

Rydin Y and Pennington M 2000, 'Public participation and local environmental planning: the collective action problem and the potential of social capital,’ Local Environment, vol. 5, no. 2, 1 May 2000, pp. 153 - 169.

Salvaris, M 1997, 'Citizenship and Progress', Conference paper presented at Measuring National Progress: A National Conference on Indicators of the Quality and Sustainability of Life in Australia, Canberra, 3-4 July 1997. <http://www.anewnz.org.nz/attachments/docs/spre-ms-citizenship-progress.doc>.

Schwarz, S, Hartnett, B, Sansom, G and Grafton, D 2007, Raising expectation? A review of NSW local government social plans, UTS Local Government Papers: 1/07, Sydney, UTS Centre for Local Government, June 2007.

Somerville, P 2005, ‘Community governance and democracy’, Policy and Politics, vol. 33, issue 1, p. 117 - 144.

Sutherland Shire Council 2009, Council considers levy for wide-ranging infrastructure program. Media release. Accessed 10 October 2010 $<$ http://www.sutherland.nsw.gov.au/ssc/home.nsf/WebPages/52CD26B53F1BBDCBC A257670001C8B0E?OpenDocument\&Expand=2>.

Wiseman, J, Heine, W, Langworthy, A, McLean, N, Pyke, J, Raysmith, H and Salvaris, M 2006, Measuring wellbeing, engaging communities: developing a community indicators framework for Victoria. The final report of the Victorian Community Indicators Project (VCIP), July 2006, State Government of Victoria Department of Human Services, VicHealth, Victorian Local Government Association (VLGA), Municipal Association of Victoria (MAV), The University of Melbourne, Victoria University and Swinburne University of Technology. < $\underline{\text { http://www.communityindicators.net.au/files/civ/20060817_VCIP_Final_Report.pdf }>}$ 
WSC 2008, Community strategic plan 2030, Wollondilly Shire Council, Adopted 21 July 2008. Accessed 14 January 2010

<http://www.wollondilly.nsw.gov.au/files/21289/File/communitystrategicplanfinal.pdf $>$.

\section{Statutes}

New Zealand Local Government Act 2002. Accessed 27 May 2009

<http://www.legislation.govt.nz/act/public/2002/0084/latest/viewpdf.aspx>.

NSWEP\&A 1997, NSW Environmental Planning and Assessment Act.

NSWLG Act 1993, New South Wales Local Government.

NSW Local Government (General) Amendment (Community and Social Plans) 1998.

NSW Local Government Act (General) Regulation 1999.

United Kingdom Local Government Act 2000. Accessed 27 May 2009

$<$ http://www.opsi.gov.uk/Acts/acts2000/ukpga_20000022_en_1\#Legislation-

Preamble>. 